\title{
Front Matter: Volume 11613
}

, "Front Matter: Volume 11613," Proc. SPIE 11613, Optical Microlithography XXXIV, 1161301 (14 April 2021); doi: 10.1117/12.2595824

SPIE. Event: SPIE Advanced Lithography, 2021, Online Only 


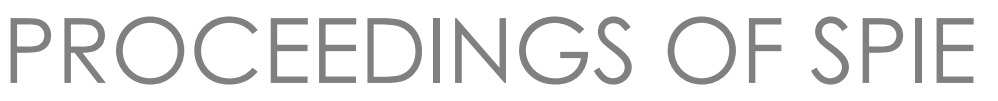

\section{Optical Microlithography XXXIV}

Soichi Owa

Mark C. Phillips

Editors

22-26 February 2021

Online Only, United States

Sponsored and Published by

SPIE

Volume 11613 
The papers in this volume were part of the technical conference cited on the cover and title page. Papers were selected and subject to review by the editors and conference program committee. Some conference presentations may not be available for publication. Additional papers and presentation recordings may be available online in the SPIE Digital Library at SPIEDigitalLibrary.org.

The papers reflect the work and thoughts of the authors and are published herein as submitted. The publisher is not responsible for the validity of the information or for any outcomes resulting from reliance thereon.

Please use the following format to cite material from these proceedings:

Author(s), "Title of Paper," in Optical Microlithography XXXIV, edited by Soichi Owa, Mark C. Phillips, Proceedings of SPIE Vol. 11613 (SPIE, Bellingham, WA, 2021) Seven-digit Article CID Number.

ISSN: 0277-786X

ISSN: 1996-756X (electronic)

ISBN: 9781510640597

ISBN: 9781510640603 (electronic)

Published by

SPIE

P.O. Box 10, Bellingham, Washington 98227-0010 USA

Telephone +1 3606763290 (Pacific Time) · Fax +1 3606471445

SPIE.org

Copyright (c) 2021, Society of Photo-Optical Instrumentation Engineers.

Copying of material in this book for internal or personal use, or for the internal or personal use of specific clients, beyond the fair use provisions granted by the U.S. Copyright Law is authorized by SPIE subject to payment of copying fees. The Transactional Reporting Service base fee for this volume is $\$ 21.00$ per article (or portion thereof), which should be paid directly to the Copyright Clearance Center (CCC), 222 Rosewood Drive, Danvers, MA 01923. Payment may also be made electronically through CCC Online at copyright.com. Other copying for republication, resale, advertising or promotion, or any form of systematic or multiple reproduction of any material in this book is prohibited except with permission in writing from the publisher. The CCC fee code is 0277 $786 \mathrm{X} / 21 / \$ 21.00$.

Printed in the United States of America by Curran Associates, Inc., under license from SPIE.

Publication of record for individual papers is online in the SPIE Digital Library.

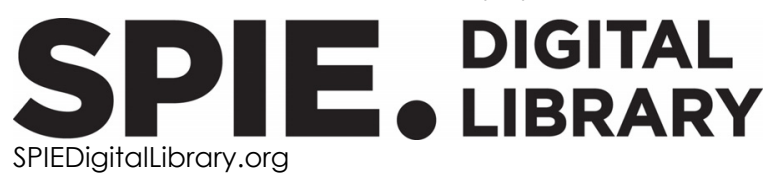

Paper Numbering: Proceedings of SPIE follow an e-First publication model. A unique citation identifier (CID) number is assigned to each article at the time of publication. Utilization of CIDs allows articles to be fully citable as soon as they are published online, and connects the same identifier to all online and print versions of the publication. SPIE uses a seven-digit CID article numbering system structured as follows:

- The first five digits correspond to the SPIE volume number.

- The last two digits indicate publication order within the volume using a Base 36 numbering system employing both numerals and letters. These two-number sets start with 00, 01, 02, 03, 04, 05, 06, 07, 08, 09, OA, OB ... 0Z, followed by 10-1Z, 20-2Z, etc. The CID Number appears on each page of the manuscript. 


\section{Contents}

MACHINE LEARNING AND COMPUTATIONALUTHOGRAPHY I

1161305 SRAF placement with generative adversarial network [11613-3]

1161306 Fast prediction of process variation band through machine leaming models [11613-4]

$1161307 \quad$ Effective data sampling techniques for machine leaming OPC in full chip production [11613-5]

1161308 Lithography tool improvement at productivity and performance with data analysis and machine leaming [11613-6]

OPIICALDIRECTWRTING AND MASK WRTING: J OINTSESSION WTH CONFRENCES 11610 AND 11613

1161309 Digital scanner, optical maskless exposure tool with DUV solid state laser (Invited Paper) [11613-7]

\section{ITHOGRAPHY EQUIPMENTAND NEW APPUCATIONS}

11613 OB A study on various c unilinear data representations and their impact on mask manufacturing flow [11613-9]

11613 OC High-resolution patteming for panel level packaging [11613-10]

\section{RESISTMODEUNG AND COMPUTATIONAL UTHOGRAPHY}

11613 OG Contour-based model calibration to a minimum number of pattems [11613-14]

$11613 \mathrm{OH} \quad$ Fast rigorous modeling of photoresist in lithography [11613-15]

11613 ol Optimization of acc urate resist kemels through convolutional neural network [11613-16]

OVERLAY CONTROLAND UTHOGRAPHY EQUIPMENT

11613 0] Qualification of small alignment mark by on-product overlay performance [11613-17] 
$116130 \mathrm{~K}$ Innovative dual mark design for alignment verification and process monitoring in advanced lithography [11613-18]

\section{MACHINE LEARNING AND COMPUTATIONALUTHOGRAPHY II}

11613 OM Advanced ILTsolutions to manufacture photonics designs [11613-21]

11613 ON The application of a new stoc hastic search algorithm "Adam" in inverse lithography technology (ILT) in critical recording head fabrication process [11613-22]

1161300 Test pattem extraction for lithography modeling under design rule revisions [11613-23]

11613 OP Machine leaming ILTfor memory customers [11613-26]

\section{POSTER SESSION}

11613 0Q Design ULVLD stepper with programmable reflective display panel as mask for multiple process wafer [11613-27]

11613 OR $\quad$ SRAF generation based on SGM/C TM contour line [11613-28]

11613 oS Lithocell availability improvement through light source maintenance cycle improvement and optimization and its availability impact analysis for cutting-edge Arfi light source [11613-29]

11613 OU Lithography layout classification based on graph convolution network [11613-31]

11613 OV Fast optical proximity comection based on graph convolution network [11613-32]

11613 OW Advanced spectral engineening: a new way of process improvements by laser spectra optimization for optical lithography [11613-33]

11613 0X Enor modeling and accuracy breakdown in optical overlay metrology for advanced nodes [11613-34]

11613 oY Enhancing model accuracy and calibration efficiency with image-based pattem selection using machine leaming techniques [11613-35] 